\title{
The Caledonian Orogeny redefined
}

\author{
W. S. McKERROW ${ }^{1}$, C. MAC NIOCAILL ${ }^{1}$ \& J. F. DEWEY ${ }^{1}$ \\ ${ }^{1}$ Department of Earth Sciences, University of Oxford, Parks Road, Oxford OXI 3PR, UK \\ (e-mail:stuartm@earth.ox.ac.uk)
}

\begin{abstract}
Recent advances in our understanding of Palaeozoic tectonics, and in the precise dating of tectonic events require exact definitions of terminology. The Caledonian Orogeny is here redefined to include all the Cambrian, Ordovician, Silurian and Devonian tectonic events associated with the development and closure of those parts of the Iapetus Ocean, which were situated between Laurentia (to the NW) and Baltica and Avalonia (to the SE and east). We suggest that the term 'Caledonian Orogeny' be restricted in this geographic sense, but that (as in modern usage) it continues to encompass a series of tectonic, or orogenic, phases (related to arc-arc, arc-continent and continent-continent collisions as Iapetus was closing). Many of these phases have been named; these and many more unnamed events are defined as orogenic phases (local components) of the Caledonian Orogeny. Some of these phases were synchronous over long distances, whereas others were diachronous. The whole Caledonian Orogeny occupied a time interval of around $200 \mathrm{Ma}$. Thus the term Caledonian should not be used to indicate age.
\end{abstract}

Keywords: Caledonian, Orogeny, Iapetus, tectonics.

\section{Historical background}

The term 'Caledonian' is derived from the Latin word for Scotland and was commonly employed in British nineteenth century literature to refer to the Scottish Highlands. The first use of the word in a tectonic sense was in 1885 by Suess (English translation: 1906, pp. 82, 201), who referred to Caledonian 'pre-Devonian mountains' extending from Norway, through Scotland to Ireland and Wales. Suess realized that tectonic events need definitions that include both geographical limits and time limits, though, in this case, he was not able to be very precise about the timing. Suess (1906, pp. 80, 83) thought that the strike of the folded beds was also characteristic of different orogens, and this was used as a criterion by several authors in the first few decades of the twentieth century (e.g. Geikie 1903, p. 394), but we now know that the strike is generally not constant in orogens.

Haug (1900) developed our concept of orogeny with an important paper in which he distinguished four major orogenies in the geological record: the Huronian at the end of the Precambrian, the Caledonian in the Early Palaeozoic, the Hercynian at the end of the Palaeozoic and the Alpine starting at the end of the Cretaceous. Haug was, as far as we can ascertain, the first geologist to use the words 'Caledonian' and 'Orogeny' in the same sentence. He was more precise than Suess about the timing of orogenies, but much less precise about their geographical extent. His work was largely ignored by British geologists, presumably because his ideas were never translated into English. Although our understanding of the causes of orogenies has increased enormously since the days of Haug we can still employ the original definition of 'Orogeny': 'the process of mountain-building'.

The third major contributor to the debate on the Caledonian Orogeny was Stille (1924), who believed that the Caledonian Orogeny was one of numerous short-lived orogenic episodes with wide (possibly world-wide) geographic distributions. Stille's paper caught the attention of British geologists and, it is only since its publication that the term 'Caledonian Orogeny' became common in the geological literature. Although the term was used in a purely geographical sense by some authors, we think that Evans \& Stubblefield (1929) were the first British geologists to refer to the Caledonian Orogeny as a mountain building event, defined both chronologically and geographically.

Today, with hindsight, it seems remarkable that so many British geologists accepted Stille's conclusion that there was a widespread orogeny at the end of the Silurian. In the British Isles, the classic, and well-studied, areas of SW Wales and Shropshire both show complete conformity between the Late Silurian and the overlying Early Devonian sediments. In fact, most Silurian sequences in the British Isles continue unbroken up to the Early Devonian (House et al. 1977). The change to non-marine Old Red Sandstone facies in Wales and Shropshire seems to have been accepted (quite wrongly) as evidence of deformation (McKerrow 1962; Hurst et al. 1978). The first widespread post-Silurian event occurred after the early Emsian (McKerrow 1988; Woodcock 1990). In Britain, it is only in the southern Midland Valley and the Southern Uplands of Scotland that there is a clear unconformity between Upper Silurian and Lower Devonian sediments (Mykura 1991). All the other British and Irish examples of Devonian rocks resting on folded Silurian beds involve younger (post-Emsian) beds immediately above the unconformity.

\section{Modern interpretations of orogenic events}

With the advent of Plate Tectonics, we can now see analogues between modern mountain-building and past events (e.g. Dewey 1969, 1975; Mitchell \& McKerrow 1975; van Staal et al. 1998; Dewey \& Mange 1999). Tectonic terms should, where possible, reflect our understanding of the processes involved. They should also be capable of easy adaptation to new interpretations. The existing terms 'orogeny' and 'phase', as at present defined, fulfil this role admirably. If 'orogenesis' is defined as 'the tectonic processes that form mountains', we can argue that the Caledonian Orogeny encompasses a series of orogenic events or phases, each of which has a defining set of time-space characteristics.

The Caledonian Orogen traditionally includes the early Palaeozoic areas of the British Isles and Scandinavia. These 


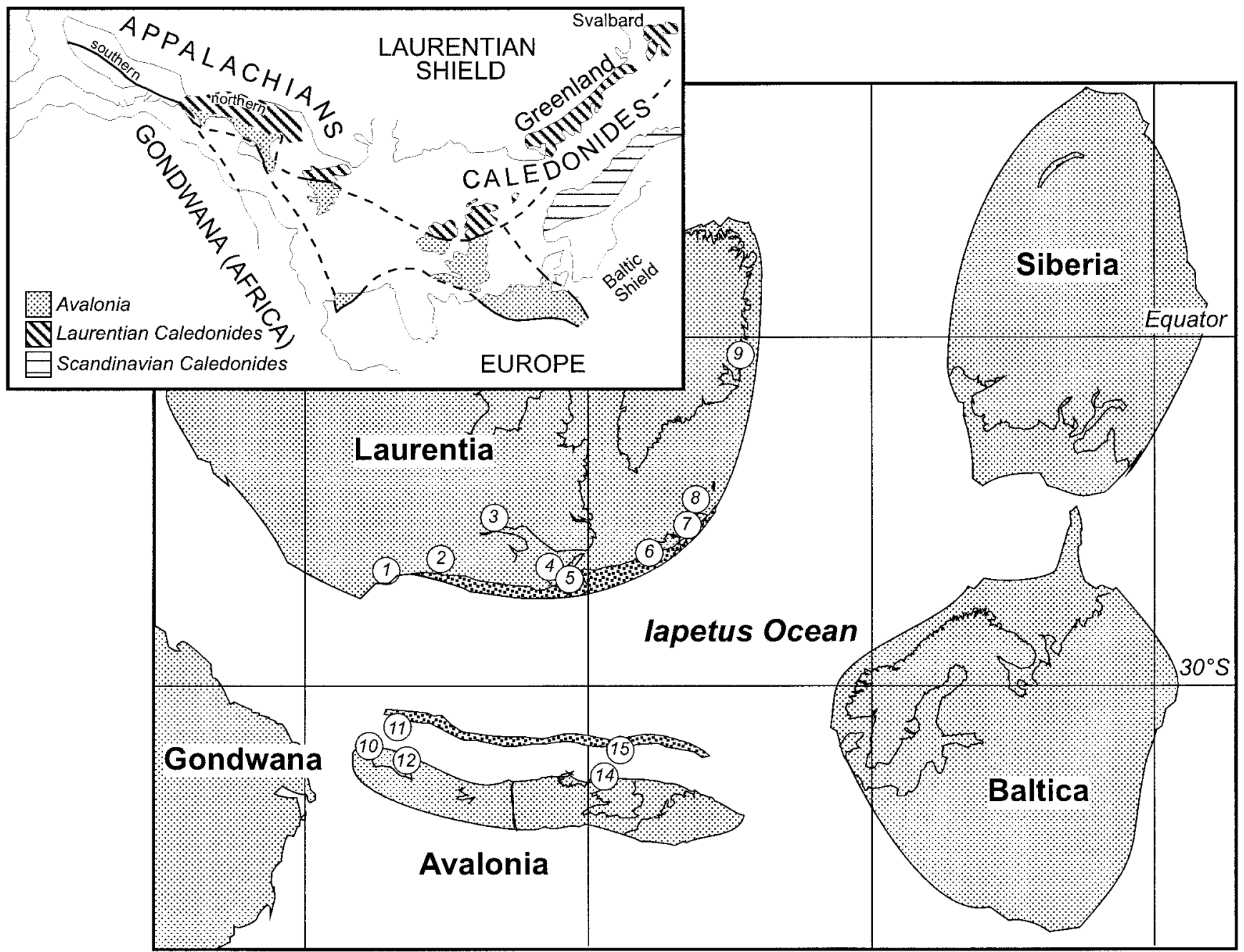

Fig. 1. Map of the Iapetus Ocean during the Caradoc (c. $455 \mathrm{Ma}$ ) showing the locations of the stratigraphic sections in Fig. 2. Two arcs are indicated diagrammatically; in reality, they each may have been composite with several subduction zones, distinct in time and place. The arc lying along the margin of Laurentia collided with that continent during the Llanvirn (in Scotland) and at various times during the Caradoc (in the Northern Appalachians), resulting in the Grampian and Taconic Phases of the Caledonian Orogeny. Different components of the arc shown north of Avalonia could have collided with this continent at different times between the pre-mid-Arenig (Penobscot Phase) and the late Caradoc (van Staal et al. 1998). The Meguma terrane of Nova Scotia (Fig. 2, column 13) probably did not collide with Laurentia until the Early Devonian, and its position in the Ordovician is uncertain, so it is not indicated on this map.

regions suffered sequences of orogenic events during the closure of the Iapetus Ocean, as did the adjacent areas of Svalbard, Greenland, Ireland and the northern Appalachians. Therefore, we extend the Caledonides to include the continental margins of Laurentia, Baltica and Avalonia bounding the Iapetus Ocean in the Ordovician and Silurian (Fig. 1), although, of course, at the time of continental rifting (c. $600 \mathrm{Ma}$ ) they may have been facing away from each other (McKerrow et al. 1992; Torsvik et al. 1996), and during their palaeogeographic evolution they may have faced different parts of that ocean. It is also clear that, because the different margins have been quite independent in their tectonic evolution (Dewey \& Ryan 1990; Dewey \& Shackleton 1984; Torsvik et al. 1996), it is not sensible to extend orogenies around the world. The margins of other Early Palaeozoic oceans had their own distinct closure histories and are thus excluded from our Caledonian orogen. In North America, Avalonia did not extend south of New England (Cocks et al. 1997), so the major Palaeozoic orogenic events south of Long Island Sound are related to the convergence of Laurentia and Gondwana, and intervening terranes, and are, therefore, also excluded from the Caledonides.

Advances in biostratigraphic precision and in isotopic age-dating now permit much more precise definition of the deformation episodes, with the result that many distinct phases are recognized. These are further outlined below. The term 'Caledonian' has often been used as a general time indicator, but this is becoming increasingly ineffective. In the past 75 years, deformation events ranging in age from Cambrian to Devonian (c. 540-400 Ma) have all been called Caledonian. Many of the shorter tectonic phases within the Caledonian Orogen are, moreover, diachronous. Clearly, it is better to use a stratigraphic scale, or an isotopic date in $\mathrm{Ma}$, to indicate the age of deformation. The use of the term 'Caledonian' has never helped to give a better understanding of the age of a tectonic event. In much recent literature the term 'Caledonian' has also been applied to igneous and metamorphic events in a chronological sense. Given that, many years ago Gilluly (1949) 
established that orogenies were random in time, we hope that the evidence presented here will deter any further use of the term in this way.

\section{Proposed nomenclature of the Caledonian Orogeny and its phases}

There are many tectonic phases within the Caledonides (e.g. Taconic, Acadian, etc.) that reflect distinct tectonic, metamorphic and igneous events, including collisions between arcs, mobile terranes and the adjacent continental margins of Laurentia, Avalonia and Baltica (McKerrow et al. 1991; Mac Niocaill et al. 1997; van Staal et al. 1998). Many of these, however, are localized, representing events (like arc-continent collisions) that only occurred locally within parts of the orogen and, in many instances, are diachronous. Nevertheless, all these Cambrian to Early Devonian tectonic events related to the history of the Iapetus Ocean are considered to be parts of the Caledonian Orogeny, and each tectonic event throughout this 200 million years can be considered as an orogenic phase. It is not essential that every local event be given a formal name, but we consider that the following names (already in the geological literature) constitute the principle phases of the Caledonian Orogeny. The interpretation of many of these phases has changed since they were first named, but we can still employ the original term as they each have sufficiently welldefined time and geographic limits, and many have a type locality. Few of Stille's orogenic phases have precise geographical limits, and when they do have a geographical indicator it is seldom related to any region adjacent to the Iapetus Ocean, so we largely ignore them here. It should also be noted that, in addition to Stille, others have proposed names for tectonic events in the Caledonides and Northern Appalachians which are not employed here; the following list is not necessarily comprehensive. Further knowledge can be expected to lead to revisions of the phase names mentioned here.

Penobscotian Phase is defined (Neuman 1967) by an unconformity in eastern Maine between the Early Cambrian Grand Pitch Formation, with the trace fossil Oldhamia, and the Middle Arenig/Llanvirn Shin Brook Formation (Fig. 2, column 10). This tectonic phase is now recognized from New England, through New Brunswick to Newfoundland (Fig. 2, columns 11, 12,13), and is interpreted as the result of the obduction of the Penobscot Arc onto the Ganderian/ Avalonian margin of Iapetus in the Tremadoc between 490 and $485 \mathrm{Ma}$ (van Staal et al. 1998, pp. 224-5, 230). This phase is also present in North Wales (Fig. 2, column 14) below the Gwynedd Supergroup (Woodcock 1990) and in SE Ireland (Brück et al. 1979).

Kennedy (1958) and McKerrow (1962) observed that the Late Precambrian/Cambrian Dalradian sequences of the Scottish Highlands were deformed in the Ordovician. Lambert \& McKerrow (1976) recognized that this deformation was distinctly earlier than the post-Silurian movements elsewhere in Britain (which, following Stille, were still called 'Caledonian') and coined the term Grampian 'Orogeny'. The Grampian Phase (Fig. 2, column 8) is now considered to be related to the collision in the Llanvirn of an arc (possibly the Arenig Ballantrae arc: Fig. 2, column 7) with Laurentia (Dewey \& Mange 1999; Soper et al. 1999), and not, as Lambert \& McKerrow thought, to the impingement of a mid-ocean ridge with the northern margin of Iapetus. The Humberian Phase in western Newfoundland and the Taconian Phase in the mainland Maritimes and New England (Fig. 2, columns 1, 2, 3 , 6) are also related to arc-continent collisions and are regarded as direct lateral equivalents of the Grampian Phase. These latter two phases range in age from basal Arenig (480 Ma) in Newfoundland (van Staal et al. 1998, pp. 220-1) to Caradoc (455 Ma) in New England (Bird \& Dewey 1970). Robinson et al. (1998), Ratcliffe et al. (1998) and Karabinos et al. (1998) provide recent interpretations of Taconian events. The Finnmarkian Phase may represent an Early Ordovician event in Scandinavia, which may or may not be analogous to the Taconic Phase (Ramsay et al. 1985; Stephens \& Gee 1985; Gee 1987).

Toghill (1992) named a basal Ashgill unconformity in Shropshire and eastern Wales (Fig. 2, column 14) as the Shelveian event. We now term this the Shelveian Phase. When Ashgill beds are present, this break is seen to quite distinct from the late Ashgill drop in sea level (Brenchley \& Newall 1984; Woodcock 1990). The early Ashgill is probably the time when Avalonia collided with Baltica with the closure of Tornquists Sea (McKerrow et al. 1991). A pedant may wish to exclude it from events in the Iapetus, and hence from our definition of the Caledonian Orogeny. The Shelveian Phase is absent in those parts of the Caledonides remote from the Tornquist Sea like the Howgill Fells (Kneller et al. 1994) or Ireland (Williams et al. 1972). In the Lake District, in northern England east of the Howgill Fells, the break in sedimentation between the Borrowdale Volcanic Group and the Windermere Super Group (Kneller et al. 1994) may be related simply to sub-aerial erosion of the lavas rather than to closure of Tornquist.

The Scandian Phase covers the Wenlock-Emsian(?) emplacement of the major nappes in Scandinavia (Stephens \& Gee 1985). A related episode may be present in Scotland where the Early Devonian Lower Old Red Sandstone rests unconformably on Wenlock beds in the southern Midland Valley and the Southern Uplands (Mykura 1991; McKerrow et al. 1991).

Although the Acadian Phase has long been recognized in the Northern Appalachians, Emsian deformation events are now known to be present in many parts of the British Isles, where many sequences also show a continuous record from the Silurian through much of the Early Devonian (McKerrow 1988; Woodcock 1990). The beds above the Acadian unconformity vary in age from Eifelian to Frasnian, and it is possible that the folding is later in Quebec and other parts of the Northern Appalachians (Fig. 2). This event has been correlated with the impingement of the Meguma terrane with the Nova Scotia margin of Laurentia (van Staal et al. 1998). It is also coincident with the migration of non-marine fish and flora across the Rheic Ocean between Gondwana and the northern continent of Laurussia (McKerrow et al. 2000). The Acadian Phase occurs throughout the Northern Appalachians, in much of the southern parts of the British Isles (McKerrow 1988), and in the Brabant Massif of Belgium; Emsian folding is absent in Cornwall, south Devon and the Ardennes so it can be inferred that the Rheic Ocean did not close everywhere at this time. Robinson et al. (1998) have recognized some Late Silurian deformation in southern Maine, which may be related to an earlier onset of the Acadian Phase.

\section{Summary}

The term 'Caledonian Orogeny' should be restricted to tectonic events within, and on the borders of, the Iapetus 


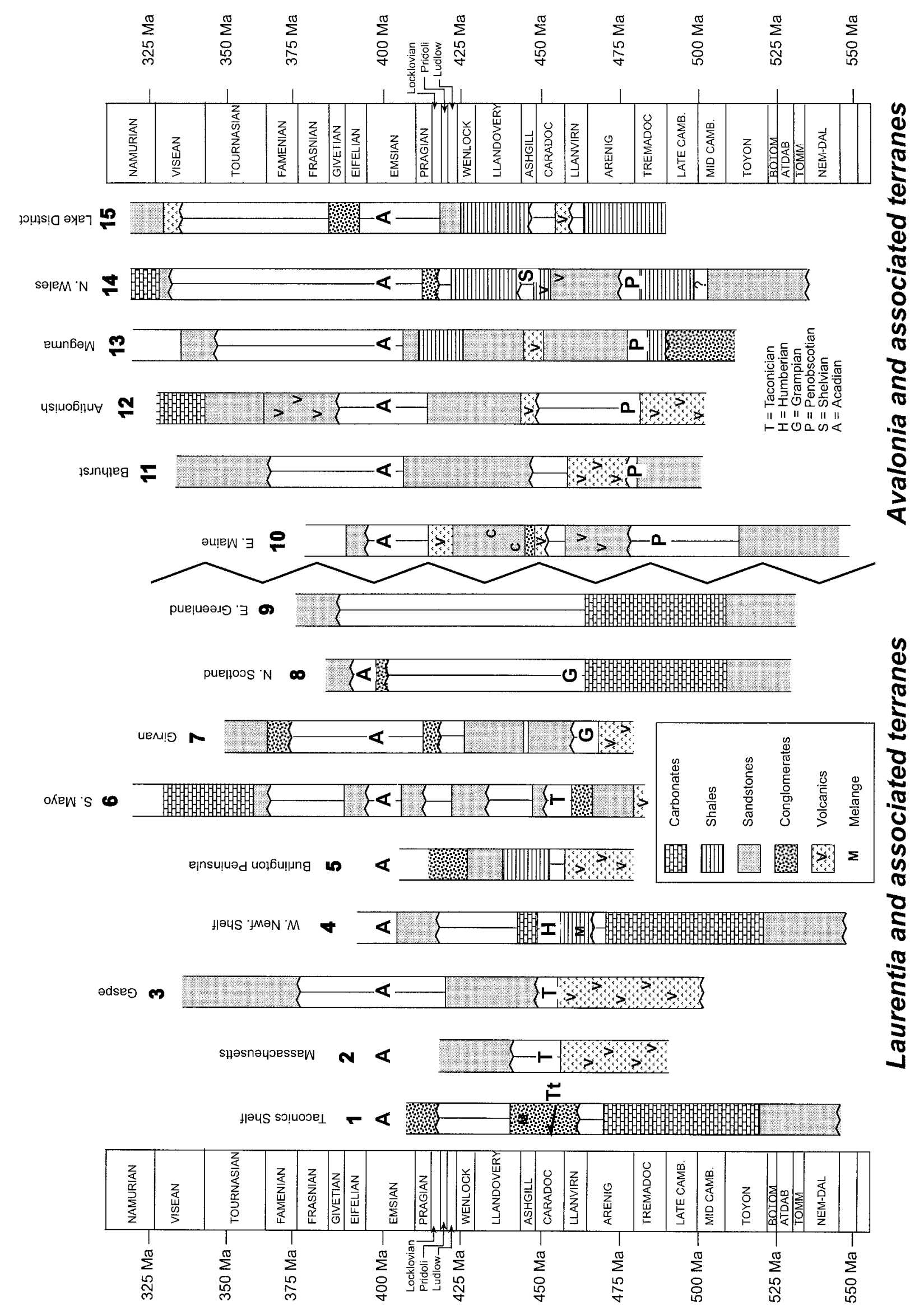


Ocean. It can be divided into numerous orogenic phases, not all of which need to be individually named. It should be noted that the earlier phases (both those named above and the many with no formal name) involve arc-arc or arc-continent collisions, while the later ones (Shelveian, Scandian and Acadian) result from continent-continent collisions. Both types of event can be diachronous, and should never be used as a basis for long-range correlation.

We thank W. de Vos, T. Harris, B. Murphy, T. Prave, P. Robinson, and $\mathrm{T}$. Torsvik for helpful discussions of earlier versions of this paper.

\section{References}

Arnott, R.J., McKerrow, W.S. \& Cocks, L.R.M. 1985. The tectonics and depositional history of the Ordovician and Silurian rocks of Notre-Dame Bay, Newfoundland. Canadian Journal of Earth Sciences, 22, 607-618.

BIRD, J.M. \& DeweY, J.F. 1970. Lithospheric plate-continental margin tectonics and the evolution of the Appalachian Orogen. Geological Society of America Bulletin, 81, 1031-1060.

Boucot, A.J., Dewey, J.F., Dineley, D.L., Fletcher, R., Fyson, W.K., Griffin, J.G., Hickox, C.F., McKerrow, W.S. \& Ziegler, A.M. 1974. Geology of the Arisaig area, Antigonish County, Nova Scotia. Geological Society of America. Special Papers, 139

Bourque, P.-A., Malo, M. \& Kirkwood, D. 2000. Paleogeography and tectono-sedimentary history at the margin of Laurentia during Silurian to earliest Devonian time: the Gaspé Belt, Quebec. Geological Society of America Bulletin, 112, 4-20.

Brenchley, P.J. \& Newall, G. 1984. Late Ordovician environmental changes and their effect on faunas. In: Bruton, D.L. (ed.) Aspects of the Ordovician System. University of Oslo, 65-79.

Brück, P.M., Colthurst, J.R.J., Feely, M., Gardiner, P.R.R., Penney, S.R., Reeves, T.J., Shannon, P.M., Smith, D.G. \& Vanguestaine, M. 1979. South-east Ireland: Lower Palaeozoic stratigraphy and depositional history. In: Harris, A.L., Holland, C.H. \& Leake, B.E. (eds) The Caledonides of the British Isles-reviewed. Geological Society, London. Special Publications, 8, 533-544.

Cocks, L.R.M., McKerrow, W.S. \& van StaAl, C.R. 1997. The margins of Avalonia. Geological Magazine, 134, 627-636.

Cooper, A.H., Millward, D., Johnson, E.W. \& Soper, N.J. 1993. The early Palaeozoic evolution of northwest England. Geological Magazine, 130, $711-724$.

Dewey, J.F. 1969. Evolution of the Appalachian/Caledonian orogen. Nature, 222, 124-129.

- 1975. Finite plate evolution: some implications for the evolution of rock processes at plate margins. American Journal of Science, 275a, 260-284.
— \& Mange, M.A. 1999. Petrography of Ordovician and Silurian sediments in the Western Irish Caledonides: tracers of a short-lived Ordovician continent-arc collision and the evolution of the Laurentian Appalachians/ Caledonian margin. In: MaC Niocaill, C. \& Ryan, P.D. (eds) Continental Tectonics. Geological Society, London. Special Publications, 164, 55-107. \& RYAN, P.D. 1990. The Ordovician evolution of the South Mayo trough, western Ireland. Tectonics, 9, 887-902.

— \& Shackleton, R.M. 1984. A model for the evolution of the Grampian tract in the early Caledonides and Appalachians. Nature, 312, 115-121.

Evans, J.W. \& Stubblefield, C.J. 1929. Handbook of the geology of Great Britain. Murby, London.

GEE, D.G. 1987. Early Caledonian tectonothermal activity in the Scandes-the Finnmarkian and Trondheimian episodes. Geologiska Föreningens I Stockholm Förhandlingar, 109, 343-345.

GeIKIE, A. 1903. Text-book of Geology, 4th Edition. Macmillan, London.

George, T.N., Johnson, G.A.L., Mitchell, M., Prentice, J.E., Ramsbottom, W.H.C., Sevastopolo, G. \& Wilson, R.B. 1976. A correlation of Dinantian rocks of the British Isles. Geological Society of London. Special Report, 7.

GILLULY, J. 1949. Distribution of mountain-building in geological time. Bulletin of the Geological Society of America, 60, 561-590.

Graham, J.R., Leake, B.E. \& Ryan, P.D. 1989. The Geology of South Mayo, Western Ireland. Scottish Academic Press.

Hatcher, R.D., Thomas, W.A. \& Viele, G.W. (eds) 1989. The AppalachianOuachita Orogen in the United States. The Geology of North America, F-2. Geological Society of America.

HAUG, E. 1900. Les géosynclinaux et les aires continentales. Bulletin de la Société Géologique de France, 12, 409-421.

House, M.R., Richardson, J.B., Chaloner, W.G., Allen, J.R.L., Holland, C.H. \& Westoll, T.S. 1977. A correlation of Devonian rocks of the British Isles. Geological Society, London, Special Reports, 7.

Hurst, J.M., HANCOCK, N.J. \& MCKerRow, W.S. 1978. Wenlock stratigraphy and palaeogeography of Wales and the Welsh Borderland. Proceedings of the Geologists' Association, 89, 197-226.

INGHAM, J.K. 1978. Geology of a continental margin 2: middle and late Ordovician trangression, Girvan. Geological Journal Special Issue, 10, 163-176.

Karabinos, P., Samson, S.D., Hepburn, J.C. \& Stoll, H.M. 1998. Taconian orogeny in the New England Appalachians: collision between Laurentia and the Sherbourne Falls Arc. Geology, 26, 215-218.

KenNedy, W.Q. 1958. The tectonic evolution of the Midland Valley of Scotland. Transactions of the Geological Society of Glasgow, 23, 106-133.

KeppIE, J.D. 1985. The Appalachian collage. In: Gee, D.G. \& Sturt, B.A. (eds) The Caledonide Orogen-Scandinavia and related areas. Wiley, Chichester, $1217-1226$.

Kneller, B.C., Scott, R.W., Soper, N.J., Johnson, E.W. \& Allen, P.M. 1994. Lithostratigraphy of the Windermere Supergroup, Northern England. Geological Journal, 29, 219-240.

Fig. 2. Stratigraphic sections at the sites indicated in Fig. 1. Timescale after McKerrow \& van Staal (2000). Tt, Taconian thrusts; M, mélange; $\mathrm{C}$, conglomerates; V, volcanic rocks. The orogenic phases indicated by letters were normally short-lived and did not extend for the full duration of the stratigraphic breaks shown. Laurentia and associated terranes. Column 1: Taconic Range, New York: shelf facies (Dewey \& Mange 1999, fig. 2, column C); Caradoc (Taconic Phase) thrusting of basin facies over margin of Laurentia. Column 2: Central Massachusetts: Bronson Hill Arc with post-Taconic cover rocks (Dewey \& Mange, fig. 2, column F), now thought to have collided with Avalonia prior to final closure of Iapetus Ocean (van Staal et al. 1998). Column 3: South Gaspé, Quebec: Laurentian margin sequences deformed in Caradoc and Emsian (Williams 1995, pp. 130, 192, 335, 343; Bourque et al. 2000, fig. 4, columns 17-19). Column 4: West Newfoundland: Taconic thrusting in Llanvirn (Dewey \& Mange 1999, fig. 2, column G). Column 5: Burlington Penninsula, Notre Dame subzone, Newfoundland: (Arnott et al. 1985, fig. 2; Williams 1995, p. 147). Column 6: Western Ireland: Lough Nafooey arc covered by Llanvirn, then folded before Llandovery and again after Silurian (Dewey \& Mange 1999, fig. 17, column G.; Graham et al. 1989; George et al. 1976, p. 54, column I). Column 7: Girvan: Arenig ophiolites and arc deformed and suceeded by Llanvirn to Wenlock cover with some arc detritus in Llanvirn and Llandeilo. Folding prior to Emsian (Stone \& Rushton 1983; Ingham 1978; Mykura 1991). Column 8: Northern Scotland: Cambrian and Early Ordovician clastic and carbonates on Precambrian (Wright \& Knight 1995); Old Red Sandstone in Orkney (Mykura 1991). Column 9: East Greenland: Cambrian and Ordovician overlain by Devonian (Dewey \& Mange 1999; Roberts 1988). Avalonia and associated terranes. Column 10: Eastern Maine: Victoria Arc sequence (van Staal et al. 1998) with cover rocks (Neuman 1984, p. 1191; Hatcher et al. 1989, plate 3, column 17). Column 11: Bathurst area, New Brunswick: Early Ordovician back-arc sequence thrust over a passive margin; covered by Silurian foredeep followed by Salinic Uplift (van Staal \& de Roo 1995; Winchester \& van Staal 1995). Column 12: Antigonish, Nova Scotia: Avalonian Cambrian volcanics overlain by an Ashgill to Early Devonian shelf sequence; then Acadian deformation before deposition of Middle Devonian to Carboniferous cover (Boucot et al. 1974; Williams 1995, pp. 360-5, 496). Column 13: Meguma, Nova Scotia: Pre-Tremadoc (possibly equivalent to Penobscot), and Emsian (Acadian) deformations (Williams 1995, p. 378; Keppie 1985). Column 14: North Wales: End Tremadoc back arc; early Arenig collision; and Emsian folding (Woodcock 1990; McKerrow 1988). Column 15: Lake District: Ordovician arc overlain Late Ordovician to Silurian cover. Acadian deformation followed by undated ORS facies (Cooper et al. 1993; McKerrow 1988). 
Lambert, R.St.J. \& McKerrow, W.S. 1976. The Grampian Orogeny. Scottish Journal of Geology, 12, 271-292.

Mac Niocaill, C., van der Pluijm, B.A. \& Van der Voo, R. 1997. Ordovician paleogeography and the evolution of the Iapetus Ocean. Geology, 25, $159-162$.

MCKerrow, W.S. 1962. The chronology of Caledonian folding in the British Isles. Proceedings of the National Academy of Sciences, 48(11), 1905-1913.

- 1988. Wenlock to Givetian deformation in the British Isles and the Canadian Appalachians. In: Harris, A.L. \& Fettes, D.J. (eds) The Caledonian-Appalachian Orogen. Geological Society, London. Special Publications, 38, 437-448.

\& van Staal, C.R. 2000. The Palaeozoic time scale reviewed. In: Franke, W., HaAk, Q., Oncken, O. \& TAnner, D. (eds) Orogenic Processes. Quantification and Modelling in the Variscan Belt. Geological Society, London. Special Publications, 179, 5-8.

_ Dewey, J.F. \& Scotese, C.F. 1991. The Ordovician and Silurian development of the Iapetus Ocean. In: Bassett, M.G., Lane, P. \& Edwards, D (eds) The Murchison Symposium. Special Papers in Palaeontology, 44, $165-178$.

-, Mac Niocalll, C., Alberg, P.E., Clayton, G., Cleal, C.J. \& Eagar, R.M.C. 2000. The Late Palaeozoic relations between Gondwana and Laurussia. In: Franke, W., HaAk, V., Oncken, O. \& Tanner, D. (eds) Orogenic Processes: Quantification and Modelling in the Variscan Belt. Geological Society, London. Special Publications, 179, 9-20.

- Scotese, C.R. \& Brasier, M.D. 1992. Early Cambrian continental reconstructions. Journal of the Geological Society, London, 149, 599-606.

Mitchell, A.H.G. \& McKerrow, W.S. 1975. Analogous evolution of the Burma Orogen and the Scottish Caledonides. Geological Society of America Bulletin, 86, 305-315.

Mykura, W. 1991. Old Red Sandstone. In: Craig, G.Y. (ed.) Geology of Scotland. Geological Society, London, 297-346.

Neuman, R.B. 1967. Bedrock geology of the Shin Pond and Stacyville quadrangles, Penobscot County, Maine. US Geological Survey Professional Papers, 524-1.

— 1984. Geology and paleobiology of islands in the Ordovician Iapetus Ocean: review and implications. Geological Society of America Bulletin, 95, 1188-1201.

Ramsay, D.M., Sturt, B.A., Zwann, K.B. \& Roberts, D. 1985. Caledonides of northern Norway. In: Gee, D.G. \& Sturt, B.A. (eds) The Caledonide Orogen-Scandinavia and related areas. Wiley, Chichester, 163-184.

RatClifFe, N.M., HAMES, W.F. \& Stanley, R.F. 1998. Interpretation of ages of arc magmatism, metamorphism and collisional tectonics in the Taconian orogen of Western New England. American Journal of Science, 298, 791-797.

Roberts, D. 1988. Timing of Silurian to middle Devonian deformation in the Caledonides of Scandinavia, Svalbard, and E. Greenland. In: HARRIS, A.L. \& Fettes, D.J. (eds) The Caledonian-Appalachian Orogen. Geological Society, London. Special Publications, 38, 429-435.

Robinson, P., Tucker, R.D., Bradley, D., Berry, H.N. \& Osberg, P.H. 1998 Palaeozoic orogens in New England, USA. Geologiska Föreningens I Stockholm Förhandlingar, 120, 119-148.
Soper, N.J., Ryan, P.D. \& Dewey, J.F. 1999. Age of the Grampian orogeny in Scotland and Ireland. Journal of the Geological Society, London, 156, 1231-1236.

Stephens, M.B. \& Gee, D.G. 1985. A tectonic model for the evolution of the eugeoclinal terranes in the central Scandinavian Caledonides. In: GeE, D.G. \& SturT, B.A. (eds) The Caledonide Orogen-Scandinavia and related areas. Wiley, Chichester, 953-978.

Stille, H. 1924. Grundfragen der vergleichenden Tektonik. Gebrüder Borntraeger, Berlin.

Stone, P. \& Rushton, A.W.A. 1983. Graptolite faunas from the Ballantrae ophiolite complex and their structural implications. Scottish Journal of Geology, 19, 297-310.

SuEss, E. 1906. The face of the earth, 2, Translated by H.B.C. Sollas, Oxford.

Toghill, P. 1992. The Shelveian event, a late Ordovician tectonic episode in Southern Britain (Eastern Avalonia). Proceedings of the Geologists' Association, 103, 31-35.

Torsvik, T.H., Smethurst, M.A., Meert, J.G., Van der Voo, R., McKerrow, W.S., Brasier, M.D., Sturt, B.A. \& Walderhaug, H.J. 1996. Continental break-up and collision in the Neoproterozoic and Palaeozoic-a tale of Baltica and Laurentia. Earth Science Reviews, 40, 229-258.

van Staal, C.R. \& DE Roo, J.A. 1995. Mid-Paleozoic tectonic evolution of the Appalachian Central Mobile Belt in northern New Brunswick, Canada: collision, extensional collapse and dextral transpression. In: HibBaRd, J.P., van StaAl, C.R. \& CAwood, P.A. (eds) Current perspectives in the Appalachian-Caledonian Orogen. Geological Association of Canada. Special Papers, 41, 367-389.

_, Dewey, J.F., Mac Niocaill, C. \& McKerrow, W.S. 1998. The Cambrian-Silurian tectonic evolution of the northern Appalachians and British Caledonides: history of a complex, west and south-west Pacific-type segment of Iapetus. In: Blundell, D.J. \& ScotT, A.C. (eds) Lyell: the Past is the key to the Present. Geological Society of London. Special Publications, 143, 199-242.

Williams, A., Strachan, I., Bassett, D.A., Dean, W.T., Ingham, J.K. Wright, A.D. \& Whittington, H.B. 1972. A correlation of the Ordovician rocks of the British Isles. Geological Society, London. Special Reports, 3.

Williams, H. (ED.) 1995. Geology of the Appalachian-Caledonian Orogen in Canada and Greenland. The Geology of North America, Volume F-1. The Geological Society of America.

WinCHESTER, J.A. \& VAN STAAL, C.R. 1995. Volcanic and sedimentary terrane correlation between the Dunnage and Gander zones of the Canadian Appalachians and the British Caledonides reviewed. In: HibBard, J.P., vaN StaAl, C.R. \& CAwood, P.A. (eds) Current perspectives in the AppalachianCaledonian Orogen. Geological Association of Canada, Special Papers, 41, 95-114.

Woodcock, N.H. 1990. Sequence stratigraphy of the Palaeozoic Welsh Basin. Journal of the Geological Society, London, 147, 537-47.

WRIGHT, D.T. \& KNIGHT, I. 1995. A revised chronostratigraphy for the lower Durness Group. Scottish Journal of Geology, 31, 11-22.

Received 6 April 2000; revised typescript accepted 4 July 2000.

Scientific editing by Rob Strachan. 